\title{
Pandemics, politics and principles: business and human rights in Southeast Asia in a time of crisis
}

Edition 3, 2020

Professor Andrew Rosser, Dr Kate Macdonald and Dr Ken M.P. Setiawan

DOI: 10.37839/MAR2652-550X3.4

Business activity has been a key driver of economic dynamism in Southeast Asia and one of the main reasons for the region's growing prosperity in recent decades. It has led to increases in investment and consumption, boosted exports and, in so doing, promoted economic growth. This has in turn created jobs, improved incomes, increased governments' ability to provide social welfare, and lifted millions out of poverty.

However, business activity within the region has also been associated with a range of human rights abuses. These include violations of workers' rights; breaches of a range of fundamental and social rights as a result of environmental problems such as air pollution, water contamination, and depletion of natural resources; and extrajudicial killings of activists who challenge the negative effects of business activity.

So widespread have such abuses been that some commentators have questioned the sustainability of business models within the region. The Thai human rights activist, Patima Tungpuchayakul, for instance, has argued that the business models of many companies in Southeast Asia's seafood industry 'are not only unsustainable but dangerous'. This is because of their heavy reliance on slave labour, a scourge that persists within the region despite being expressly prohibited in international law. 
Against this backdrop, the United Nations has over the past decade sought to promote implementation of the Guiding Principles on Business and Human Rights (UNGPs) within the region. A set of guidelines for states and companies endorsed by the UN's Human Rights Council in 2011, the UNGPs provide a framework that emphasises states' responsibility to protect human rights, businesses' responsibility to respect human rights, and their joint responsibility along with civil society to ensure that victims of business-related human rights abuses have access to adequate remedies.

The COVID-19 pandemic has generated fears that business-related human rights abuses in the region will only get worse. This is because some Southeast Asian governments and businesses appear to have taken advantage of the crisis to push ahead with projects that have negative human rights impacts, limit scope for protest, and intimidate civil society organisations and human rights defenders. There have also been numerous reports of workers being laid off without due entitlements and employers failing to ensure that workers receive adequate protection against the virus in workplaces.

The UN's Working Group on Business and Human Rights, the body responsible for promoting implementation of the UNGPs, has accordingly stepped up its efforts to promote the UNGPs within the region and more widely. Earlier this year, it issued a statement declaring that ' $\mathrm{t}$ ]he responses to the pandemic and the economic impact must not result in lower standards - or even be used as a pretext by governments and business actors to circumvent international human rights commitments'. It is asserted that the UNGPs continue to apply despite the challenges presented by the pandemic.

This special issue of Melbourne Asia Review examines how the UNGPs are playing out within Southeast Asia. Bringing together contributions by scholars and human rights activists, it consists of articles exploring the origins of the UNGPs and the mechanisms through which they promise to effect change within the region (Kate Macdonald); the political dynamics surrounding implementation of the UNGPs in 
specific countries within the region-namely, Indonesia (Adzkar Ahisin et al), Myanmar (Catherine Renshaw), Philippines (Andrew Rosser), and Malaysia (Ken M.P. Setiawan); and, finally, the political dynamics surrounding the UNGPs within the Association of Southeast Asian Nations (ASEAN), an inter-governmental organisation that promotes cooperation and integration in the region (Randy Nandyatama and Muhammad Rum).

Taken as a whole, these contributions present a sobering picture with regards to the prospects for implementation of the UNGPs and improved protection of human rights within Southeast Asia. While proponents of the UNGPs express hope that the UNGPs will stimulate change through processes of learning and socialisation, these contributions show that there are significant political obstacles to change.

Foremost among these is the political dominance in many Southeast Asian countries of predatory authoritarian and oligarchic elites whose wealth and power depend on ownership or control over the business activities that generate human rights concerns. With authority over the key institutions of state (the executive, the legislature and the judiciary), these elites have been able to ignore appeals for rights-related change and block or deflect them if they materialise as concrete policy proposals.

This is notwithstanding the fact that active rights-based coalitions have emerged within the region in support of implementation of the UNGPs. Such coalitions have often been led by national human rights institutions and have included human rights NGOs, sections of the business community exposed to human rights-related business risks, as well as sympathetic academics, journalists, and other actors.

A second political obstacle to change is the growing role of China as a donor and investor within the region. In 2019, China made a commitment to observe human rights in foreign investments before the UN's Human Rights Council. In addition, China's Ministry of Commerce and Chamber of Commerce of Metals, Minerals and Chemicals Importers and Exporters has recently issued guidelines requiring Chinese 
mining firms to observe the UNGPs when operating abroad. But, as Renshaw notes in the case of Myanmar, Chinese companies operating abroad 'do not utilise the framework of the Guiding Principles on Business and Human Rights'. This seems likely to be a wider phenomenon within Southeast Asia.

A third, and final, political obstacle to change has been the compartmentalisation of policy-making and implementation-that is, its organisation into discrete spheres defined by sector. In some cases, this has resulted in the containment of UNGP norms to 'political', 'security' or 'human rights' domains rather than the 'economic' domain. Nandyatama and Rum suggest that this has been a particularly significant problem in relation to ASEAN's response to the UNGPs, but Ahisin et al's analysis suggests that it has also been a feature in Indonesia.

At the same time, the articles indicate that rights-based coalitions have been able to make some inroads in promoting implementation of the UNGPs, notwithstanding these constraints. In cases such as Indonesia and Malaysia, these have taken the form of progress in the development of national action plans on business and human rights and/or state-sponsored guidelines or roadmaps for UNGP implementation. In cases such as the Philippines and Myanmar, it has centred more on coalitionbuilding and awareness-raising on issues to do with business and human rights.

It is clear that full implementation of the UNGPs in Southeast Asia is not currently politically feasible. Nor is it likely to be so in the foreseeable future. But these limited forms of progress indicate that the business and human rights agenda has gained some traction in the region, offering some level of hope for the future. Undoubtedly continued activism by rights-based coalitions will be central to turning this modest progress into deeper and more sustained change in the future. In taking this research agenda forward, it will therefore be important to explore why these modest successes have been possible given the inauspicious nature of the wider political context, and whether and how these initial achievements could be leveraged to propel deeper change. 


\section{MELBOURNE ASIA REVIEW}

August 23, 2020

Authors: Professor Andrew Rosser, Dr Kate Macdonald and Dr Ken M.P Setiawan.

Image: Mal Taman Anggrek. Credit: Matthew Kenwrick/Flickr. 